\title{
Project for Offshore Horizontal Directional Drilling (HDD) for Pipeline Crossing in Bukit Tua, Indonesia
}

\author{
Yusuf Sofyan \\ Ariosh Engineering, Nigeria \\ *Corresponding author. email: ysofyan@yahoo.com
}

\begin{abstract}
A B S T R A C T
Horizontal Directional Drilling (HDD) is commonly associated with well exploration activity, onshore road crossing, nearshore pipeline installation, and offshore pipeline crossing which requires precise alignment of two barges from one to the other. Here, the purpose of this study was to show one of the projects that was successfully performed on December 2013 for the Bukit Tua Project in East Java, Indonesia costing USD 8 Million. From this project experience, there are 6 Best Practices in HDD Offshore Project for Pipeline Crossing Application (first in region) which will serve as a guide to future projects in replicating similar success. Out from 6 Best practices, there are two main recipes for success of HDD offshore for offshore crossings which are the drilling fluid also known as mud, and the Gyro Steering Tool (GST). First, mud parameter varies on case by case basis depending on the soil condition at the location where HDD will be performed. Failure to maintain the above parameters may result in catastrophic failure whereby the bore hole may collapse and pipe may get stuck underneath the seabed. Secondly, the beauty of GST is extremely accurate and unaffected by other metal anomalies during drilling process, thus ensuring the curve profile and direction of drilling are as per design throughout the whole process.

(c) 2016 Tim Pengembang Journal UPI
\end{abstract}




\section{INTRODUCTION}

In general, energy is defined as objects that can be transferred to other objects or converted into different forms. (Kumar et al., 2015; Benmedjahed \& Boudaoud, 2015) Based on the source, energy can be classified as thermal energy, radiant energy, electromagnetic, nuclear, etc. (Kathare \& Undre, 2016)

To produce energy, current developments still use petroleum oil. (Sharma \& Singh, 2009) Although biodiesel has been well known as one of the promising renewable energies as a biodegradable, renewable, environmentally benign, and clean-burning substitute for petroleum diesel fuel, (Farobie \& Hasanah, 2016) the use of petroleum cannot be disappeared. Therefore, strategies to get petroleum oil are inevitable. (Sucahya et al., 2016)

Horizontal Directional Drilling (HDD) is commonly associated with well exploration activity, onshore road crossing and

nearshore pipeline installation. (see https://www.pik-potsdam.de/research/pub lications/pikreports/.files/pr80.pdf\#page $=45$ 8) However, in reality, the application of HDD is also proven for offshore pipeline crossing, which requires precise alignment of two barges from one to the other. (Ryder \& Rapson, 2008; Ryder et al., 2016)

Here, the objective of this study was to show our recent practical strategy to develop offshore HDD for pipeline crossing in Bukit Tua, Indonesia (See Figure 1). To get this strategy, we can divide our targets as

1. The entire drill string length is approximately $610 \mathrm{~m}$ including a $130 \mathrm{~m}$ long tail string $350 \mathrm{~m}$ in length from the entry point to the exit point located offshore.

2. Clearance between $8-10$ meters below the existing 18 " OD Hess line.

3. The initial Water Depth is $5 m-6 \mathrm{~m}$ below MSL and crossing point in KP 83.709

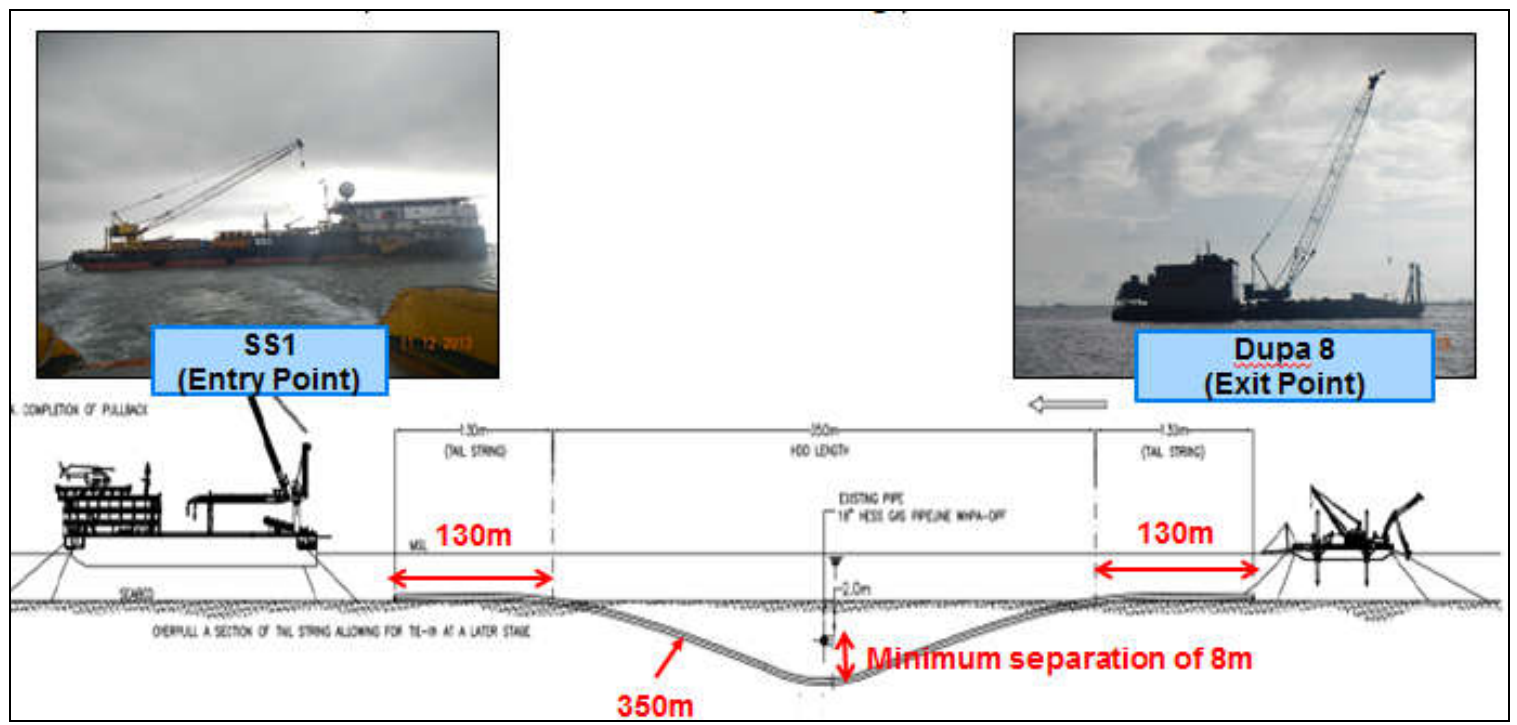

Figure 1. Offshore HDD for pipeline crossing strategy. 
In short of this study, PC Ketapang II Ltd (PCK2L), a fully subsidiary of Petronas, plans to develop Bukit Tua Field, in the Ketapang Block, East Java, Indonesia. Bukit Tua which is primarily an oil field but with significant associated gas, is located $35 \mathrm{~km}$ north of Madura Island and $110 \mathrm{~km}$ northeast of Gresik at a water depth of approximately 57 $m$. The Ketapang PSC block location is shown in Figure 2.

This application was successfully performed on December 2013 for the Bukit
Tua Project in East Java, Indonesia costing USD 8 Million. Due to local regulation prohibiting normal offshore crossing method, the new pipeline of $350 \mathrm{~m}$ length shall cross below an existing 18" pipeline owned by another Production Sharing Contract (PSC), which is already buried $2 \mathrm{~m}$ underneath the seabed at $6 \mathrm{~m}$ water depth. As mutually agreed by both PSCs, the newly installed pipeline shall satisfy minimum vertical separation of $8 \mathrm{~m}$ bottom of existing pipeline (BOP).

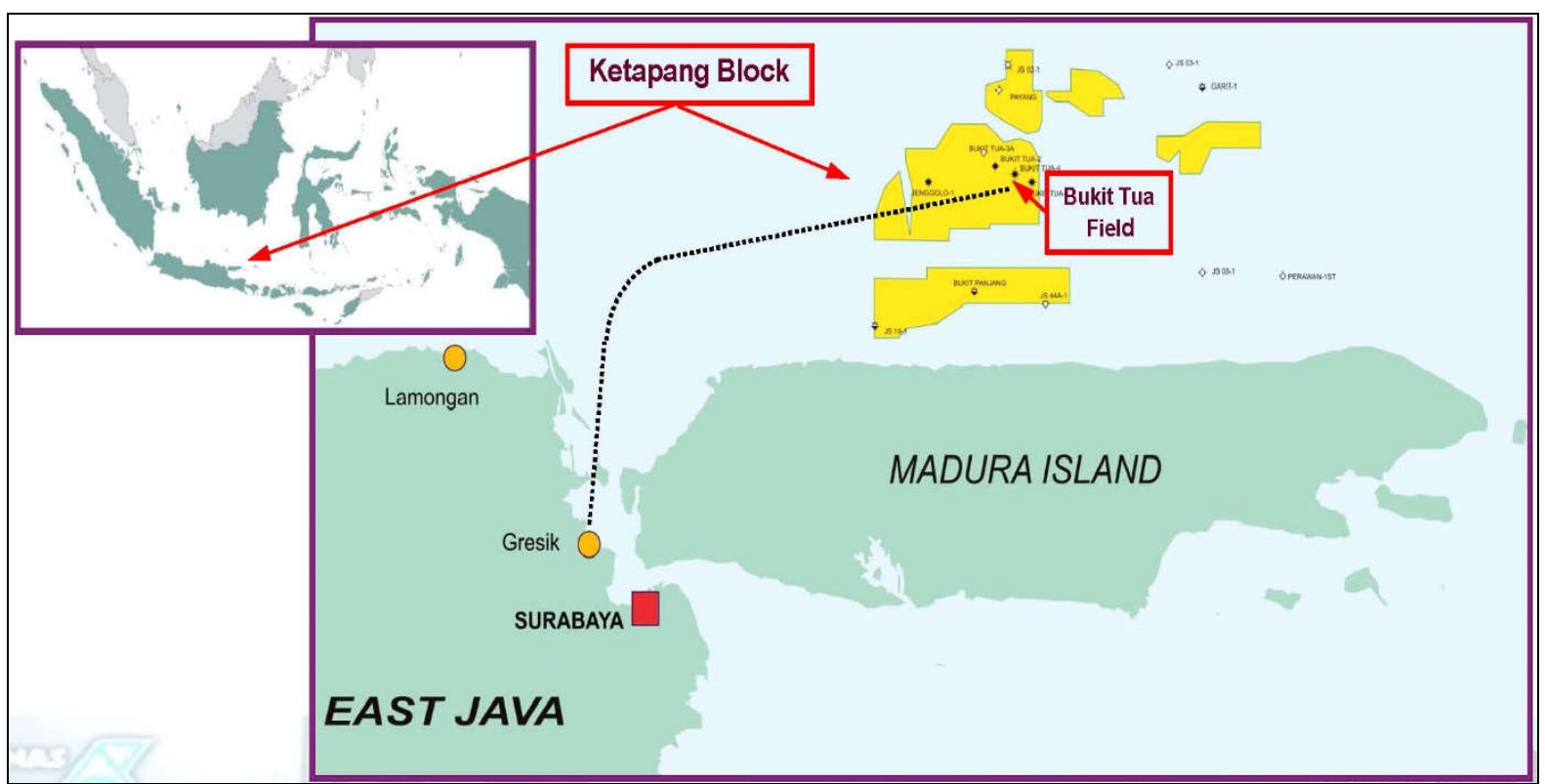

Figure 2. Bukit Tua Location.

\section{EXPERIMENTAL METHOD}

The execution for HDD Offshore can be summarized in seven best practices as below:

\subsection{HDD basic stage}

Drilling and pullback operation are carried out in four major stages (See Figure 3):
a) Pilot hole $\left(9^{\prime \prime}\right)$
b) Reaming (22" reamer for hole-opening)

c) Cleaning (18" barrel)

d) Pipe pulling (12")

It is proposed to drill the pilot hole from HDD/ Drilling barge to the Exit Barge offshore using the 125 Tonne capacity rig spread. After punching out on the seabed, a barrel reamers/ fly cutter will be used to enlarge the hole by pulling and rotating the drill string towards the HDD/ Drilling barge. After completion of the reaming operations the pipe string will be pulled. 


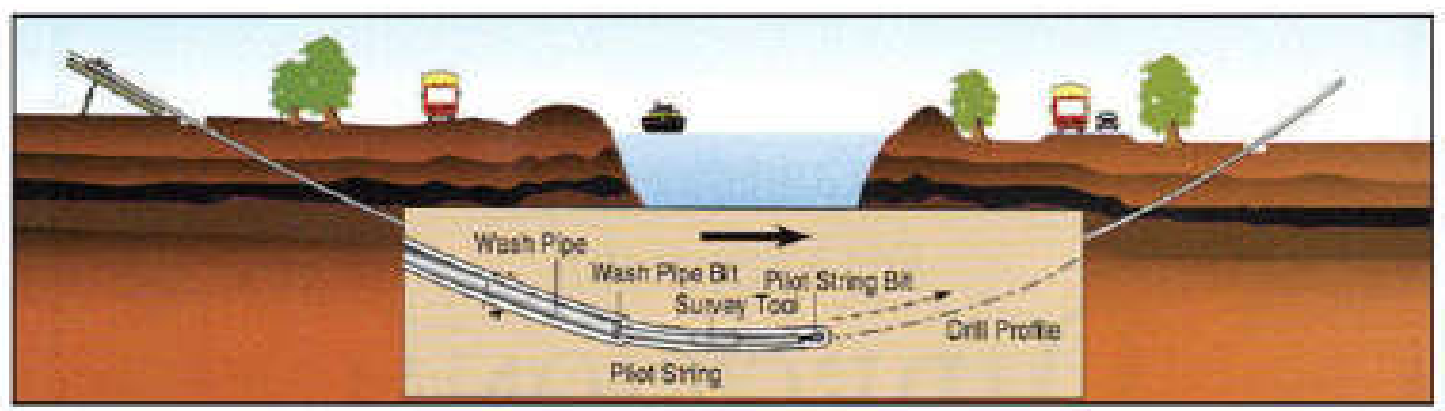

PILOT HOLE

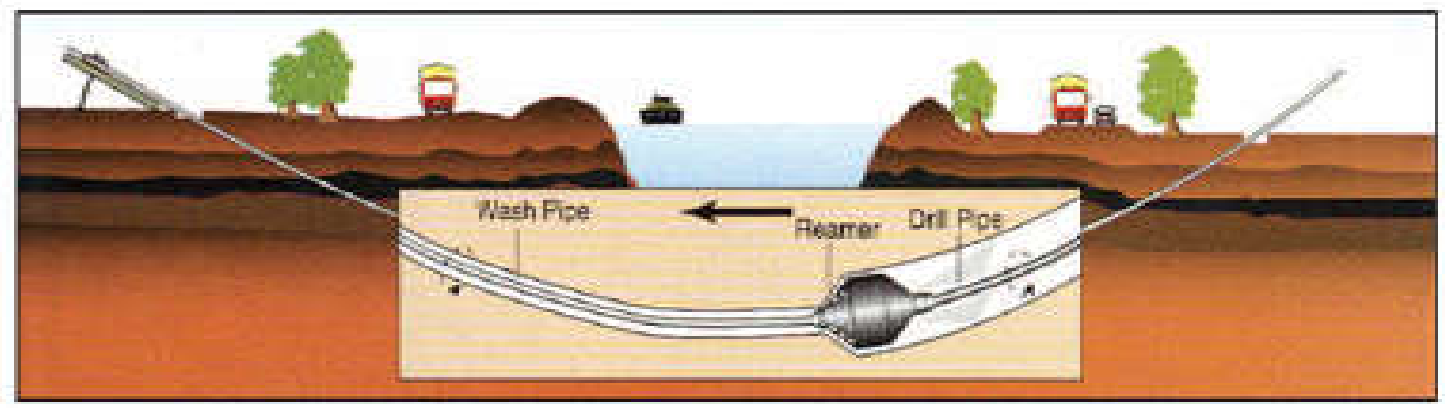

PRE-REAMING

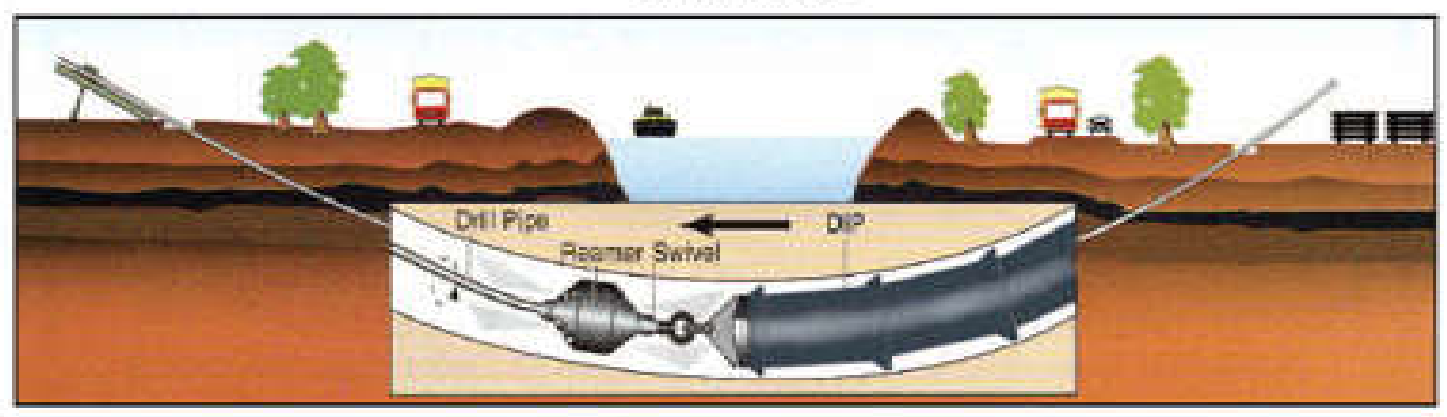

PULL-BACK

Figure 3. HDD basic stage.

\subsection{Barge Setup and Equipment Arrangement}

For HDD operation, straightness of the projected pipeline route is essential, although in shallow water depth, eight anchored barges are utilized, and equipment set up based on the required operation for soft clay type of soil.
Example of the soil is shown in Figure 4, and the construction of the equipments is shown in Figures 5 and 6 . To ensure the barge setup and equipment arrangement, the schematic flow of the process is illustrated in Figure 7. 
189 | Indonesian Journal of Science \& Technology, Volume 1 Issue 2, September 2016 Hal 185-202

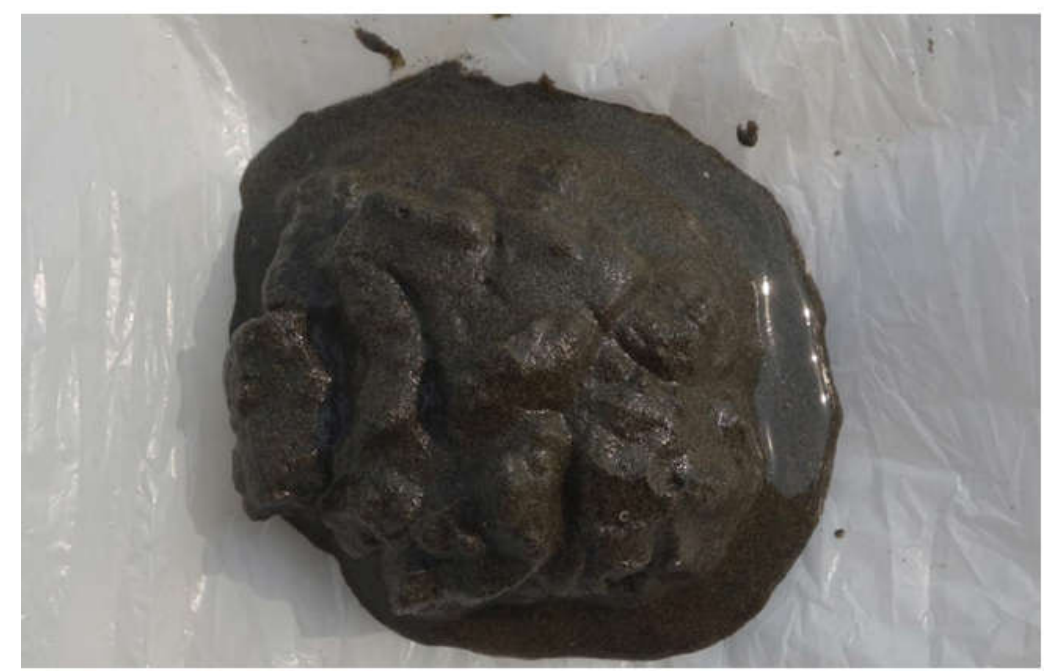

Figure 4. Photograph image of soil.

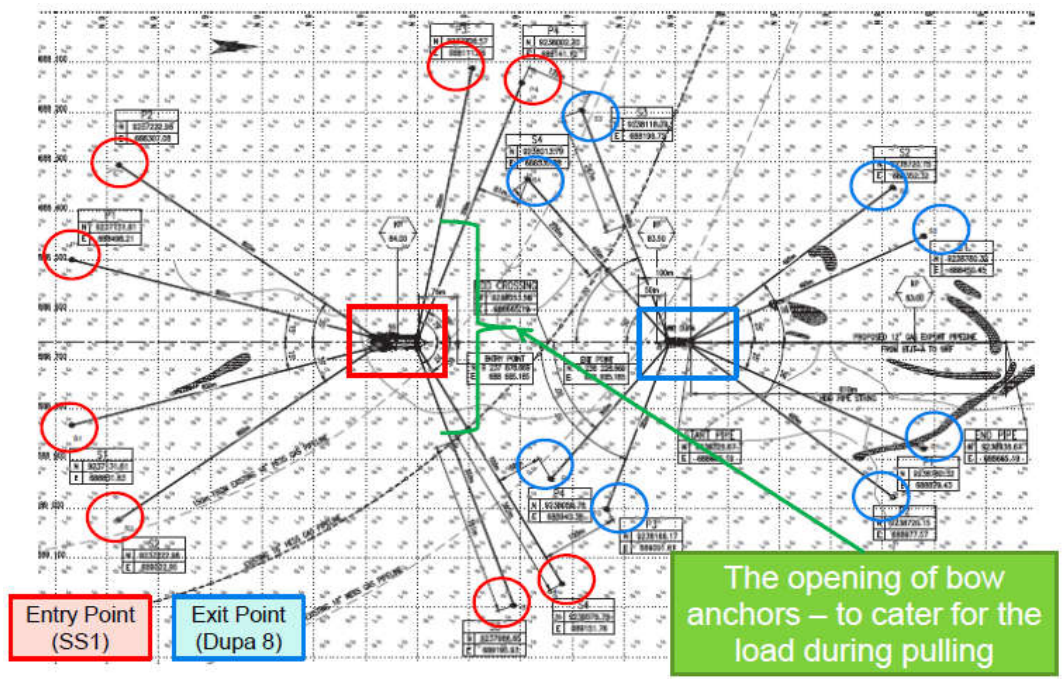

Figure 5. The opening of bow anchors to cater for the load during pulling.

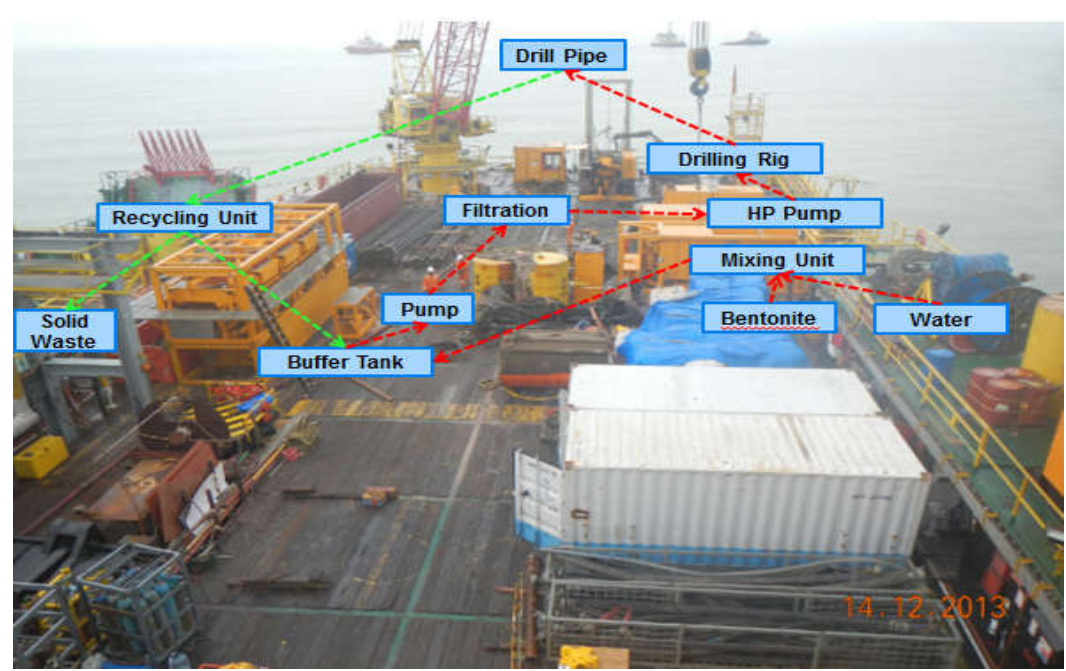

Figure 6. The photograph image of the system. 
Yusuf Sofyan. Project for Offshore Horizontal Directional Drilling (HDD) for Pipeline... | 190

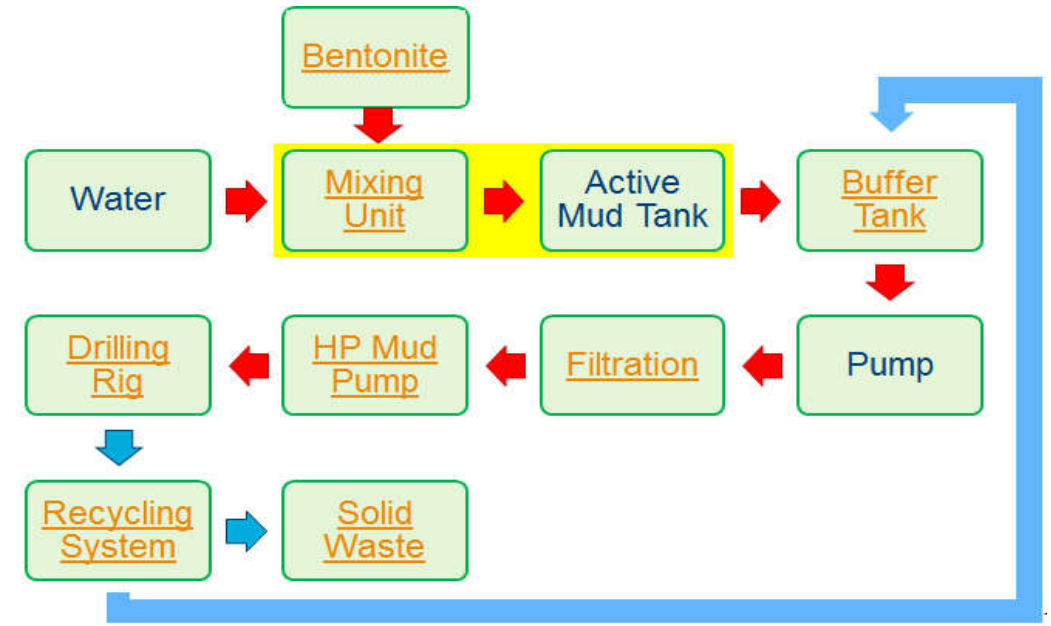

Figure 7. The schematic diagram of the process.

\subsection{Pipeline Profile Control and Check}

Gyro Steering Tool (GST) was used, and performed well (see Figures 8 and 9). Calibration shall be performed earlier and at minimum twice (facing upward and downward).

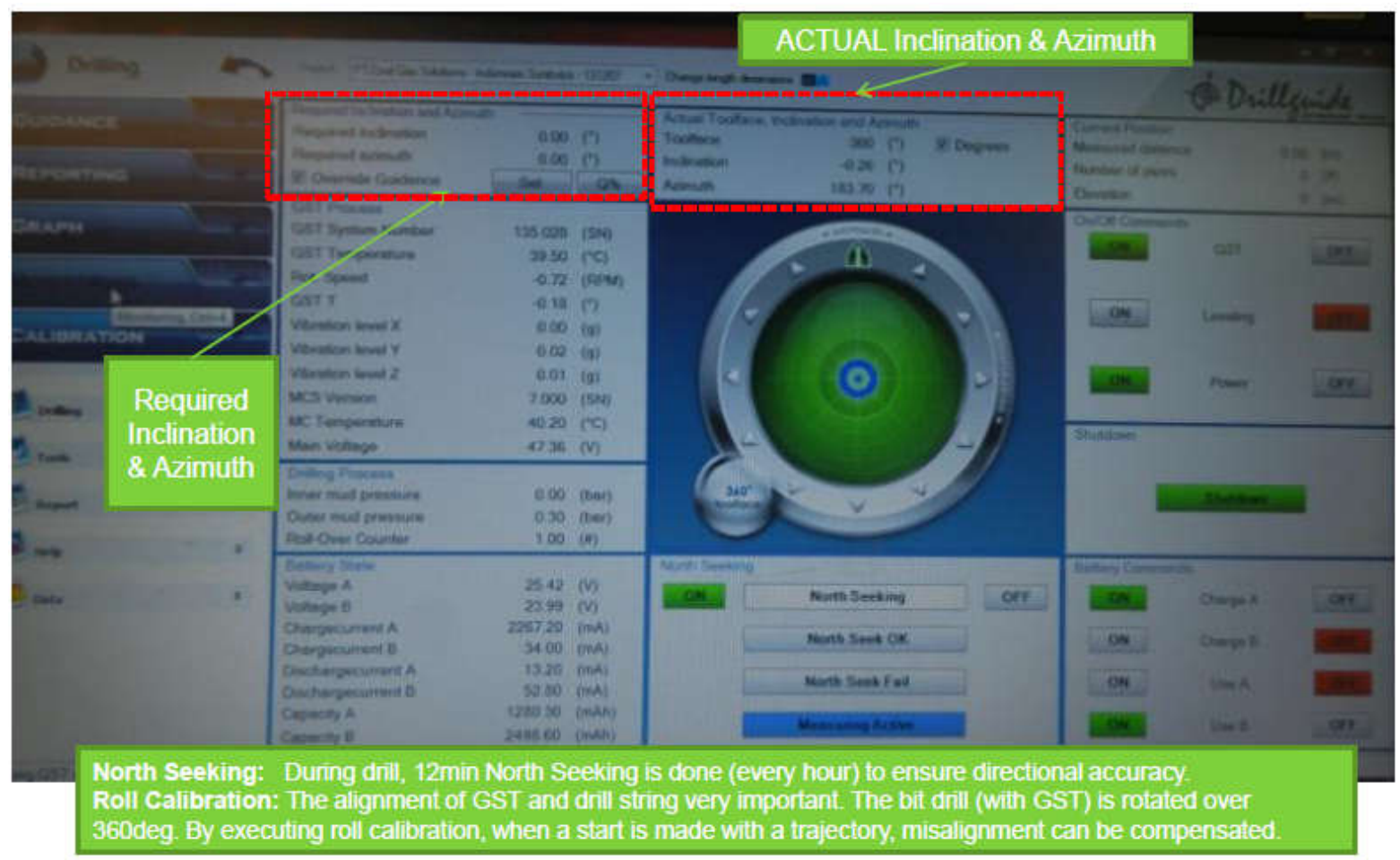

Figure 8. Check control in the computer system. 
191 | Indonesian Journal of Science \& Technology, Volume 1 Issue 2, September 2016 Hal 185-202

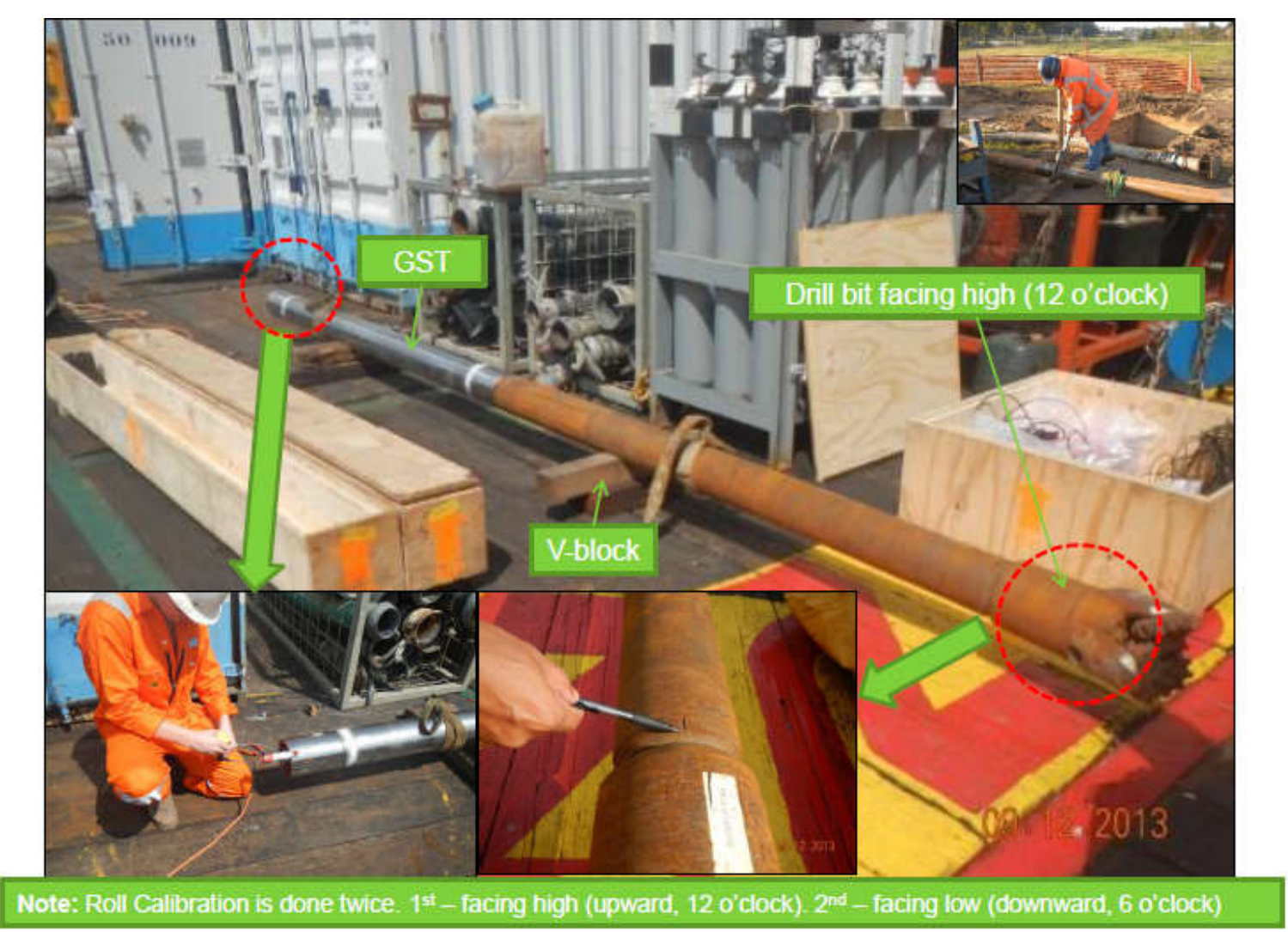

Figure 9. Check control in the field.

\subsection{Mud Mixing and Testing}

Mud mixing and testing are critical to ensure the bore hole will not collapse, especially in soft clay soil type. Three (3) major element are used i.e. Bentonite, Detergent and Viscosifier (VAC). Examples of the bentonite, detergent, and VAC are shown in Figures 10, 11, and 12, respectively.

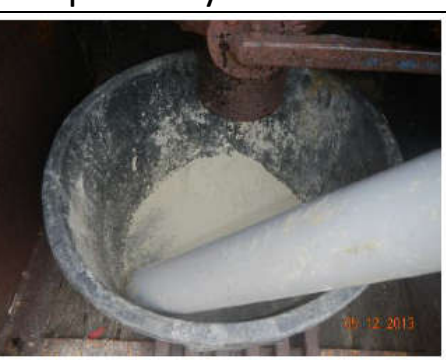

Bentonite:

- Either to use API @ OCMA

(Oil Companies Material Assoc)

- As known as = Montmorrilionite clay

- Has ability to swell approx $10-15$ times its own volume, when mixed with water

- Can encapsulate soil particle and suspense cutting during transportation.

Figure 10. Check control in the field. 


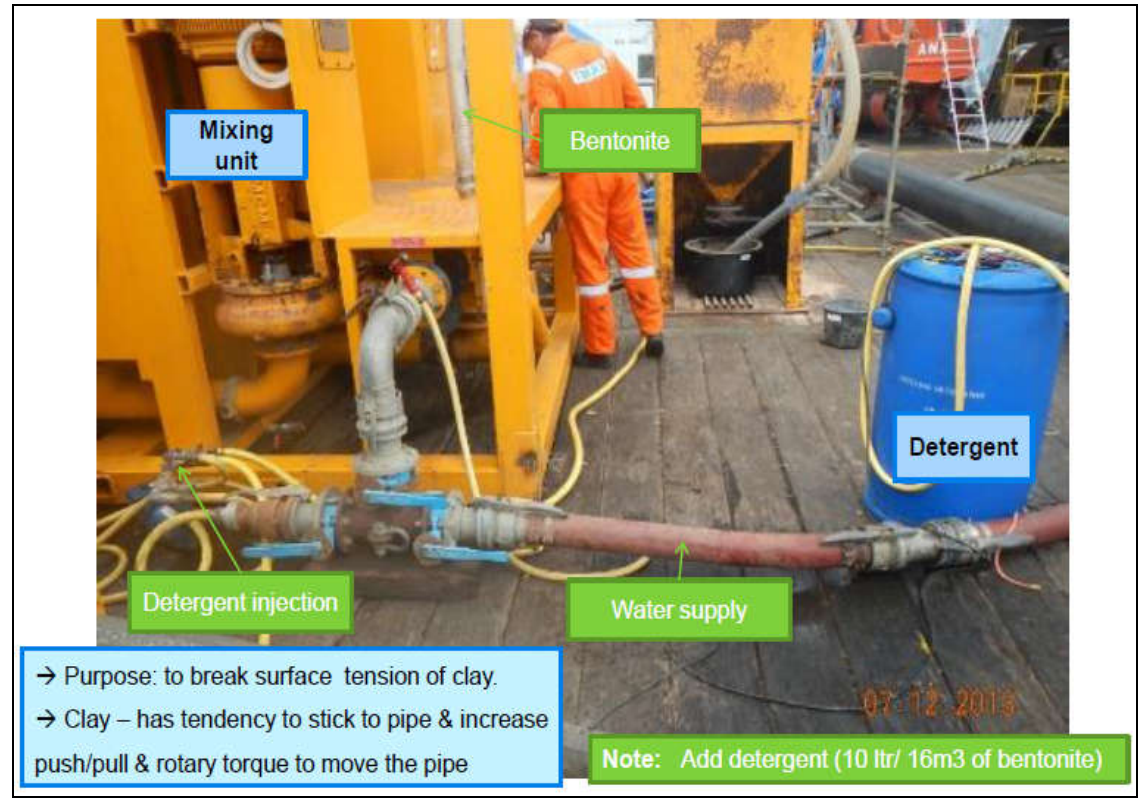

Figure 11. Appearance and information of detergent.

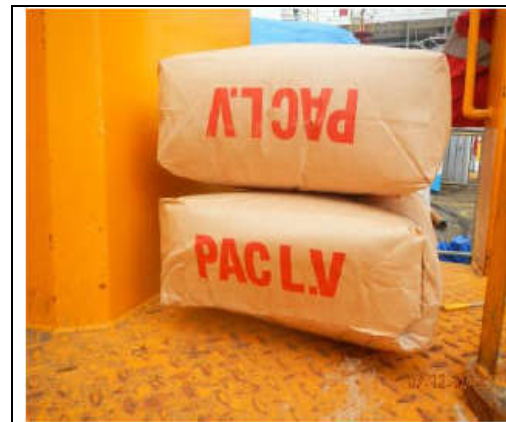

Viscosifier:

- $\quad A K A=$ Poly-Anionic Cellulose

- Used to thicken or dilute mud, when add/ reduce bentonite resulted in unacceptable mud weight.

- To get HIGH viscosity, PAC will be added to INCREASE yield point (YP), without

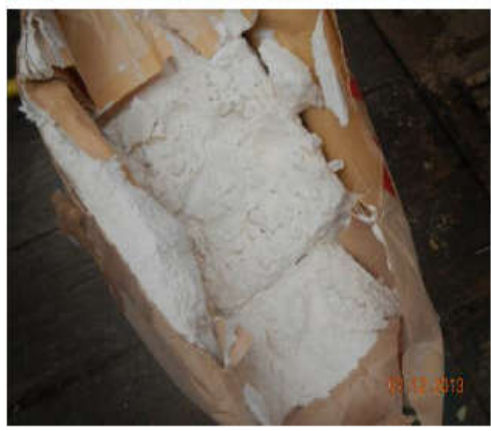
increase overall viscosity \& mud weight

- For clay, lower viscosity is required to maintain YP. So, PAC LV is used.

- PAC - can reduce flocculation of drilling mud. It happen when fresh water + salt water

Note: Add PAC-V ( $1 \mathrm{~kg} / \mathrm{m} 3$ of bentonite)

Figure 12. Appearance and information of VAC.

\subsection{HDD Preparation \& Installation}

All equipment function test, casing penetration marking and casing installation is part of HDD preparation (See Figure 13).
Casing inclination shall be ensured as per design as this is the gate to achieve the design pipeline profile. 
193 | Indonesian Journal of Science \& Technology, Volume 1 Issue 2, September 2016 Hal 185-202
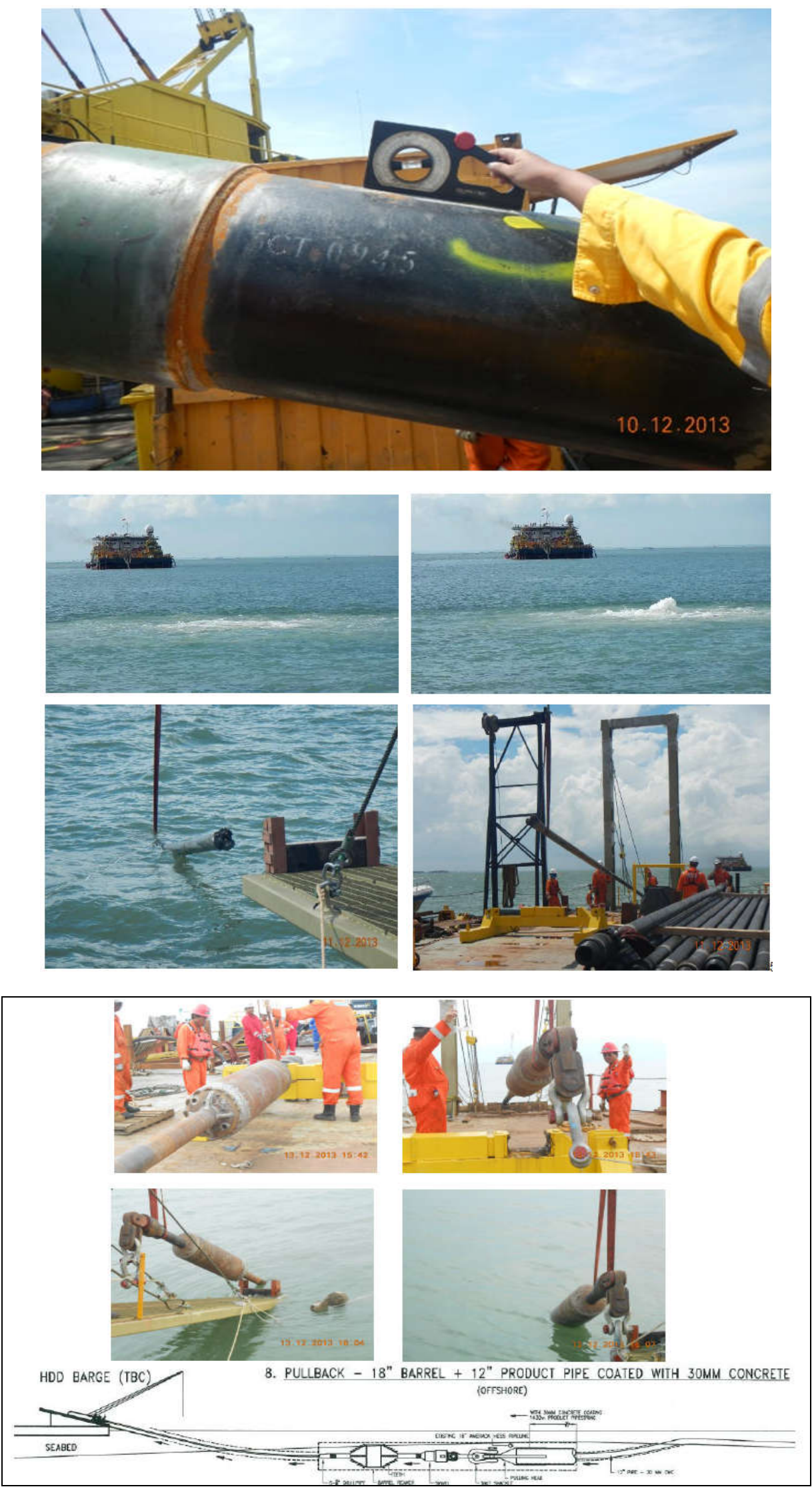

Figure 13. HDD preparation and instalation. 


\subsection{Check on HDD Result}

As the outcome for separation distance between pipelines, based on GST are within acceptance criteria.

\section{RESULTS AND DISCUSSION}

\subsection{Physicochemical properties of mud}

Prior to designing the plant, several tests must be conducted to ensure mud performance (See Figures 14-16). Based on the Figures, we found that the properties of mud are in relatively good, compared with fresh water. The results are attached in the Figure.

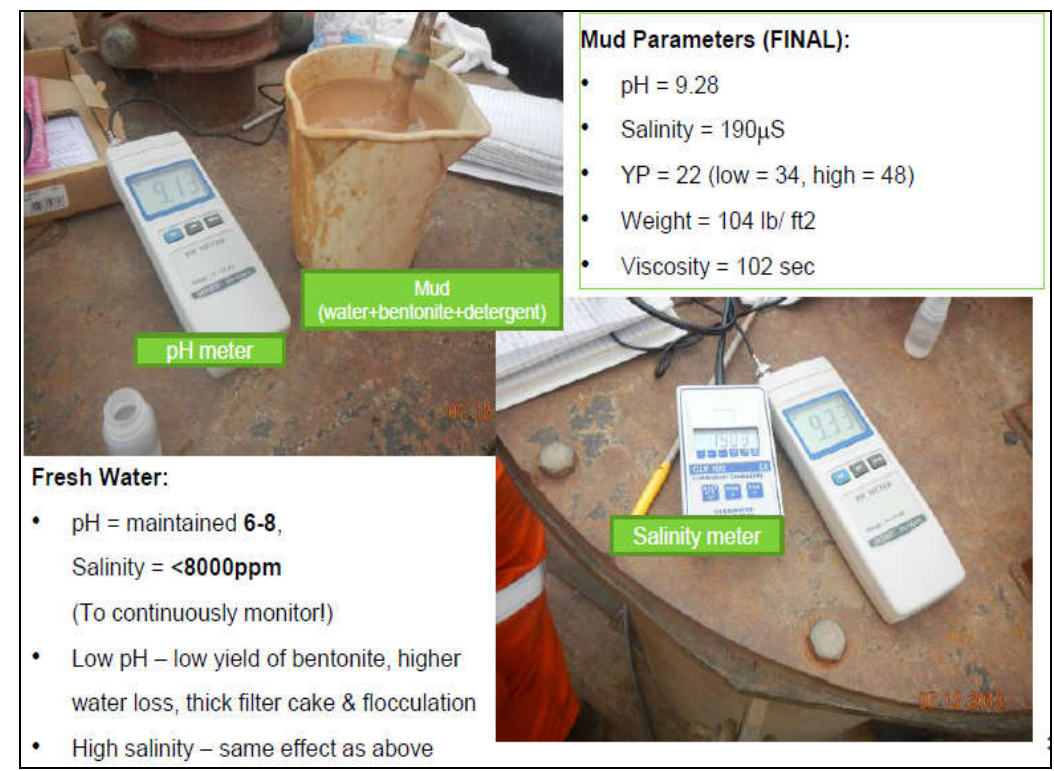

Figure 14. Mud parameters results.
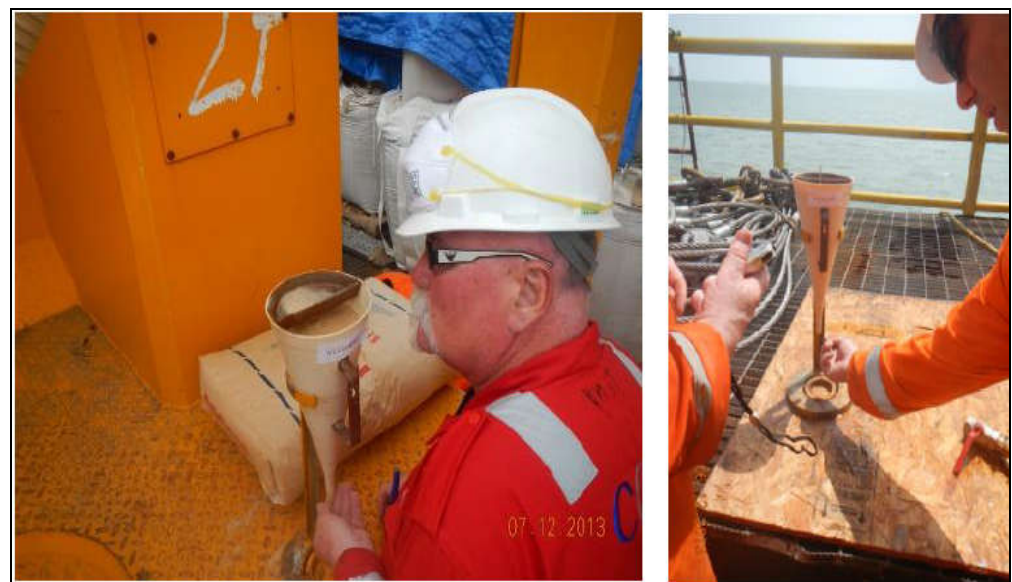

- As per API, time taken is counted to determine the viscosity of the mud

- Normally for clay $=40-50 \mathrm{sec}$, sand/ rock $=50-65 \mathrm{sec}$. i.e. $36 \mathrm{sec}$ is low viscosity

- For Ketapang project; $102 \mathrm{sec}$

Figure 15. Viscosity of Mud. 

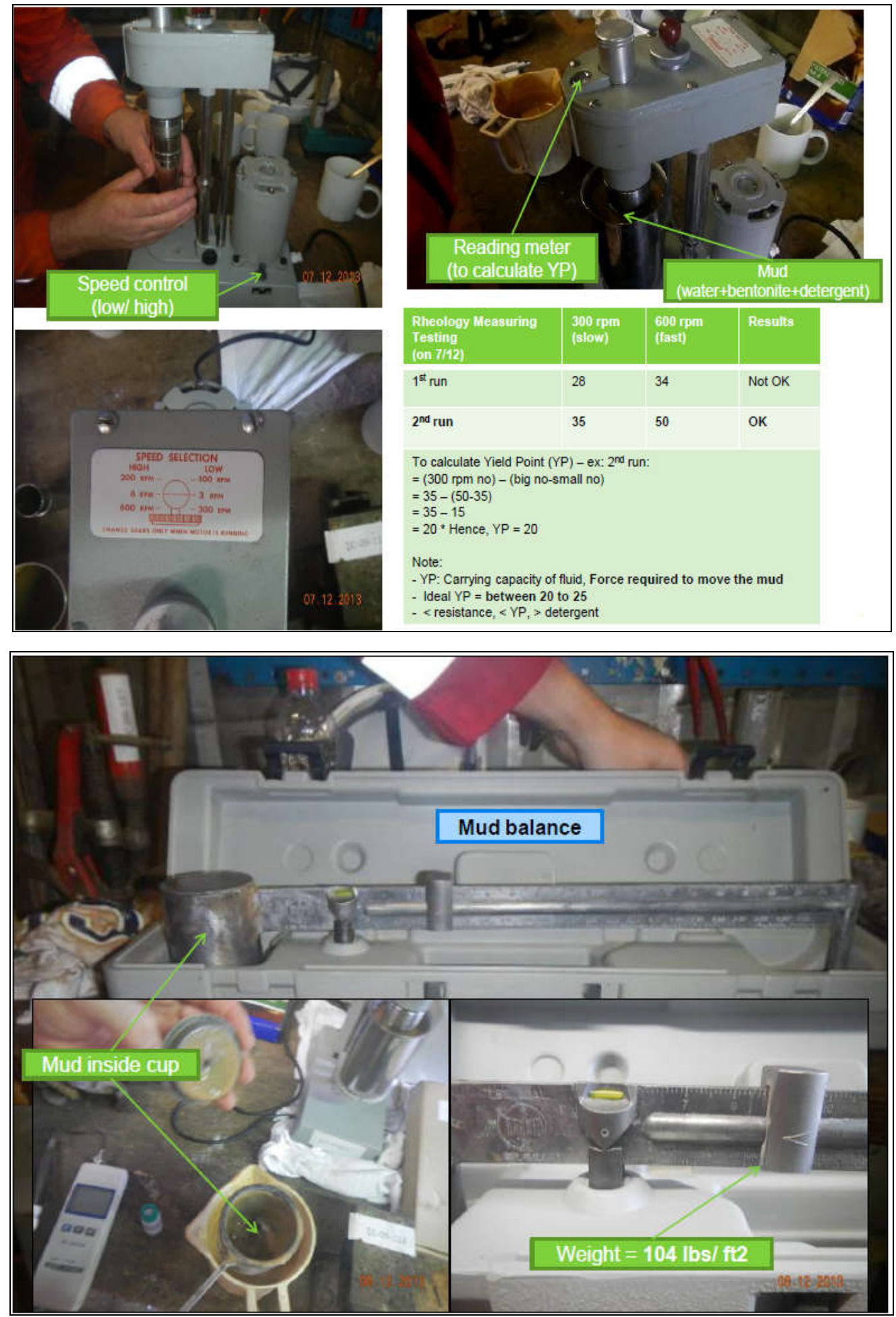

Figure 16. Equipment analysis for characterizing mud.

\subsection{Plant design for HDD in Bukit Tua}

The results of HDD are shown in Figures 17 and 18, this result also re-verify using DGPS survey showing the same result. Based on Figures 17 and 18, the initial image of
Bukit Tua Oil \& Gas Integrated Development Project is shown in Figure 19. The figure showed the possibility in how to structurize the equipment in the realistic plant. 


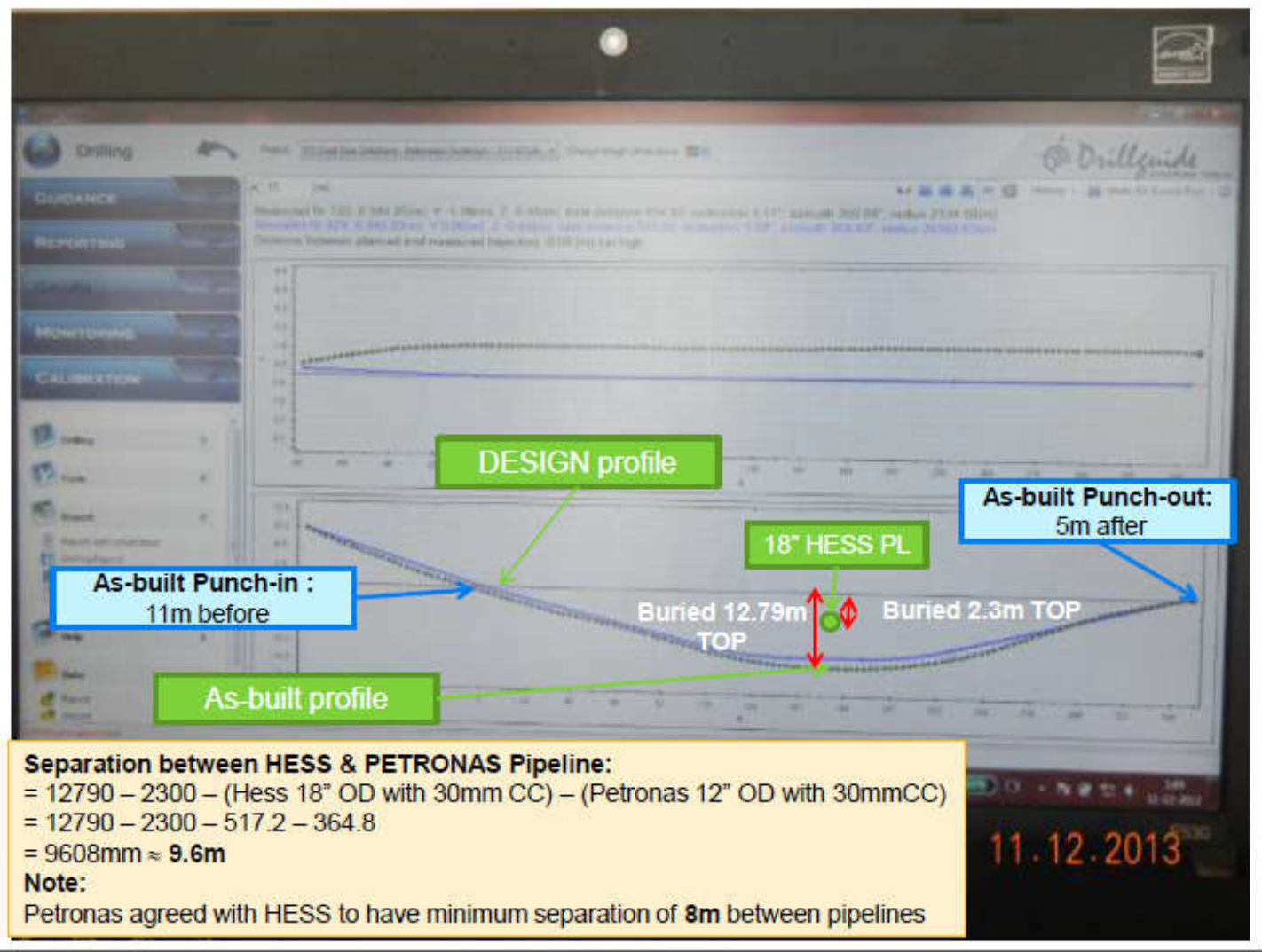

Figure 17. Results of HDD in the computer system.

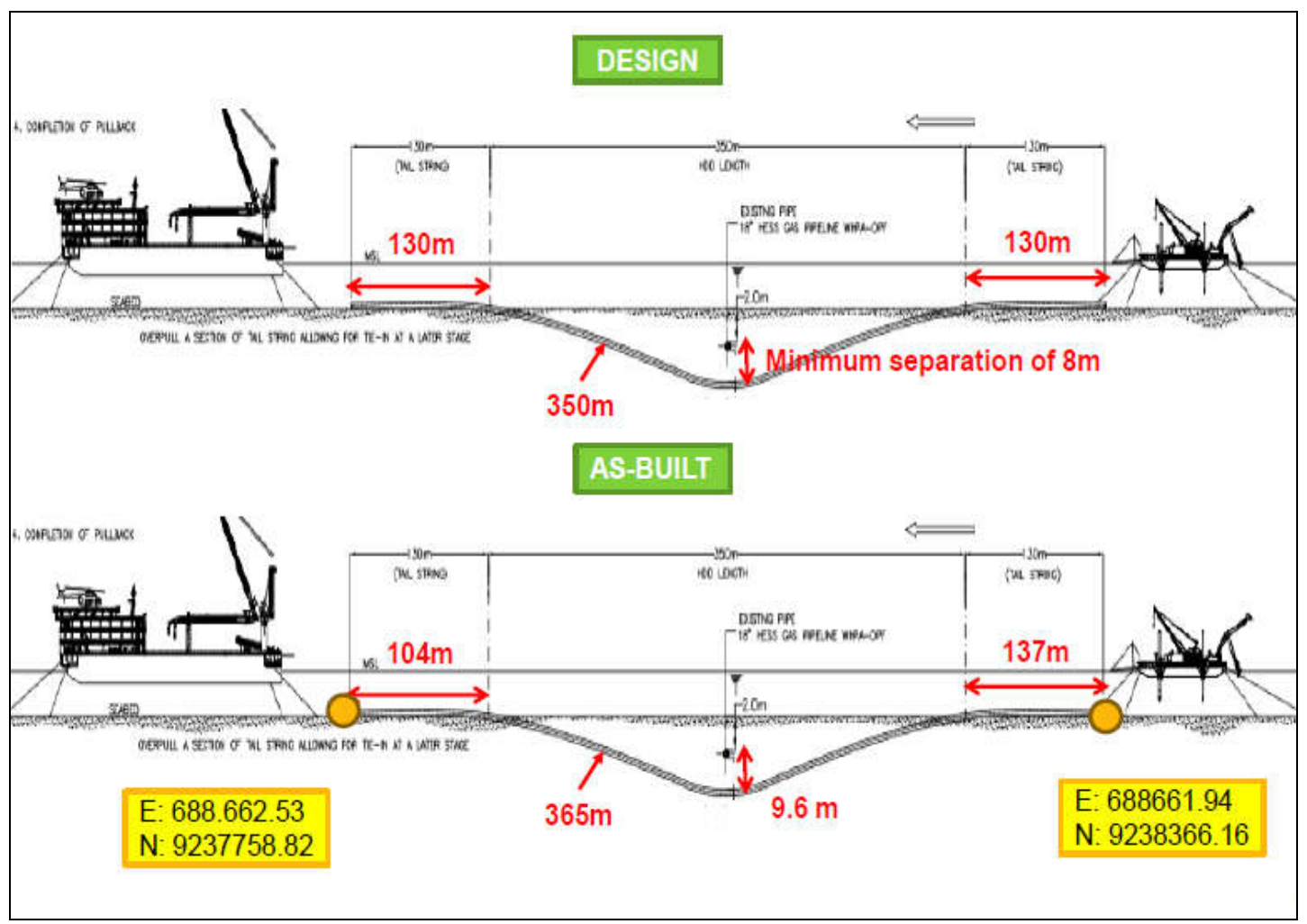

Figure 18. Results of HDD in the field. 


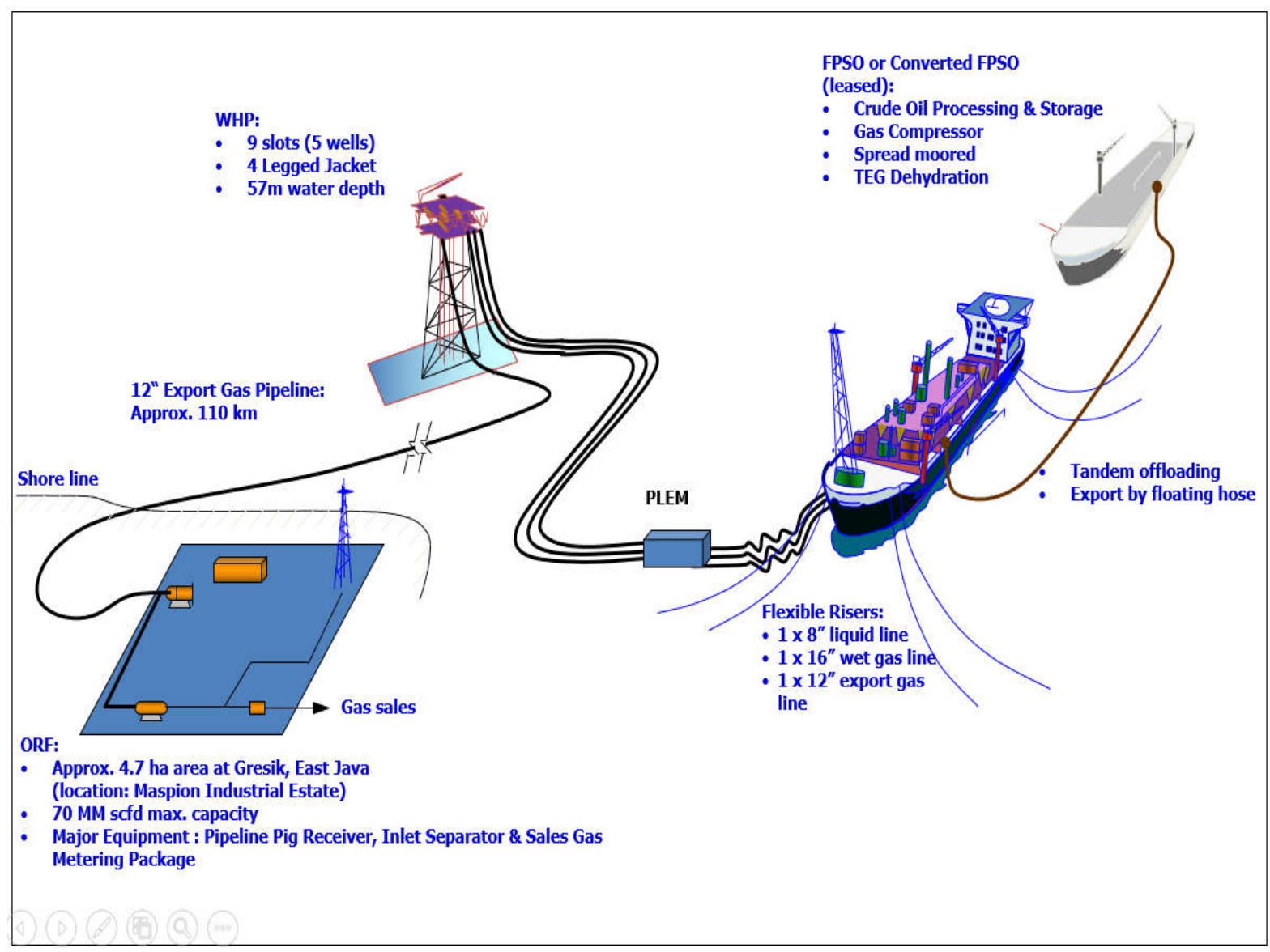

Figure 19. Bukit Tua Development Schematic.

The development consist of a Well Head Platform (WHP) that is tied back to a spreadmoored Floating Production, Storage and Offloading (FPSO), anchored approximately $700 \mathrm{~m}$ away. The WHP will consist of 9 slots (with 5 production wells, 2 future production wells and 2 future water flooding wells) as well as liquid, wet gas and gas export risers.

Two separate single phase infield flowlines, 16" for wet gas and 8" for combined liquid (oil and water) will deliver the produced fluids from the WHP to the FPSO. Associated gas is compressed and conditioned on the FPSO and exported via a
12 " gas pipeline to WHP and there onwards to Onshore Receiving Facilities (ORF) via $110 \mathrm{~km} 12$ " Gas Export Pipeline. The doublehull and dual-classed FPSO (ABS and BKI) is capable to store oil up to 631,323 barrels with offloading rate of $20 \mathrm{Kboph}$. The FPSO topsides facilities are designed to handle maximum of $25 \mathrm{Kbopd}$ and $77 \mathrm{MMScfd}$ of oil and gas respectively.

Based on the above consideration, Bukit Tua Field Development concept was revised due to WHP subsidence incident and the new development concept. The revised plant is shown in Figure 20. 


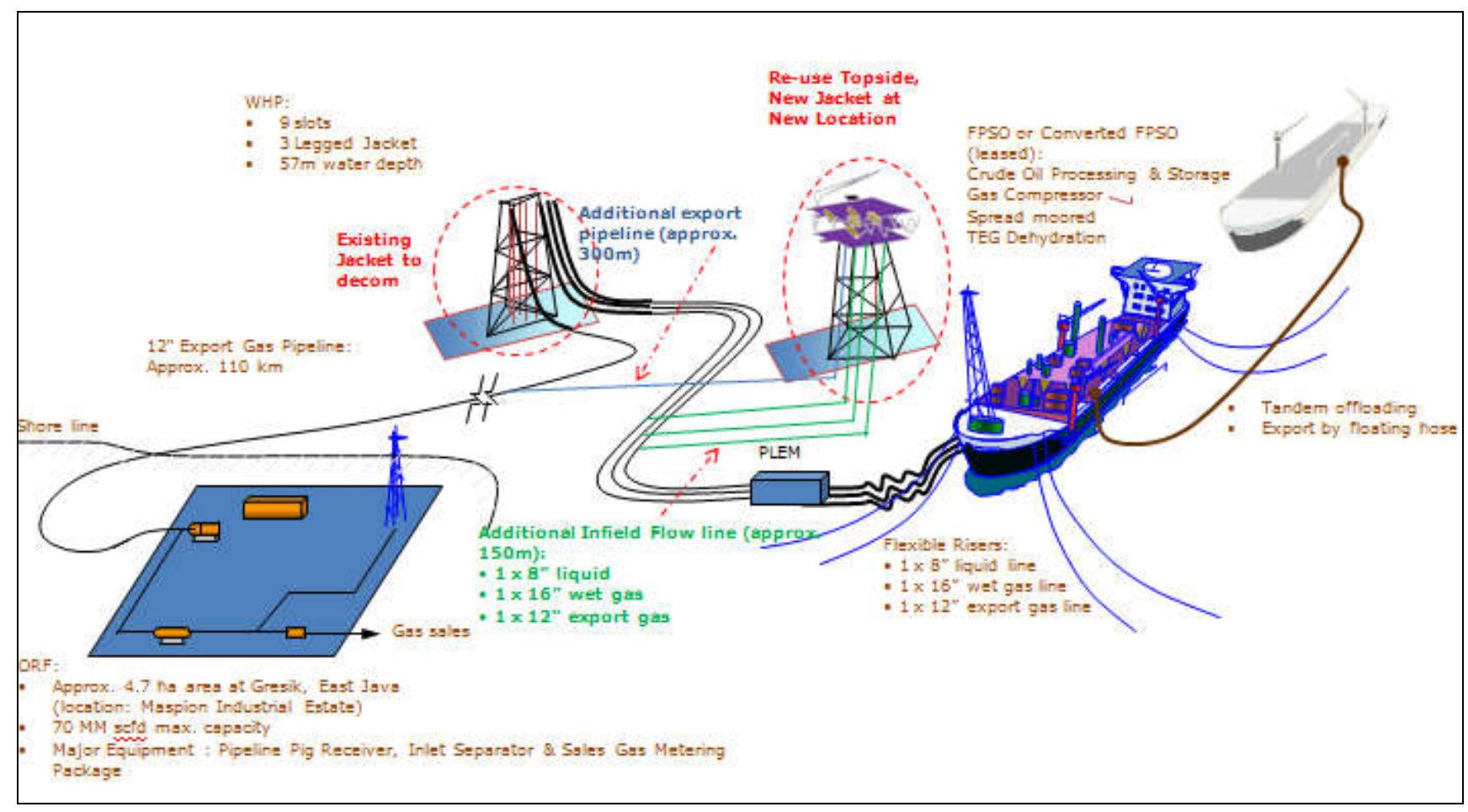

Figure 20. Revised Bukit Tua Development Concept Schematic (initial).

The major changes of facilities concept after the tilting incident are

1. Wellhead Platform (WHP): Initially WHP was designed for 3-legged sub-structure jacket. However, after the subsidence incident happened, it was redesigned to 4-legged with support of adaptor to suit the connection between original topside to new-fabricated 4-legged jacket.

2. Floating Production Storage \& Offloading vessel (FPSO): The FPSO initially shall be moored approximately $900 \mathrm{~m}$ away from the WHP. With the new location of new WHP, the FPSO is now moored much closer, approximately $700 \mathrm{~m}$ away.
3. Reroute of Infield flow lines and Export Pipeline to new WHP location.

Along the route of Export pipeline crossed with four other pipelines and one fibre optic. Three pipeline and one fibre optic crossing location are in the water depth more than $13 \mathrm{~m}$, which based on local regulation requirement can be installed with conventional pipeline crossing. However, one pipeline crossing, which location at water depth less than $13 \mathrm{~m}$. Thus, this required special crossing i.e. by lowering existing pipeline or crossed below existing pipeline to meet requirement of $2 \mathrm{~m}$ minimum burial at water depth less than 13 $\mathrm{m}$. The illustration of the pipeline in the map is shown in Figure 21. 


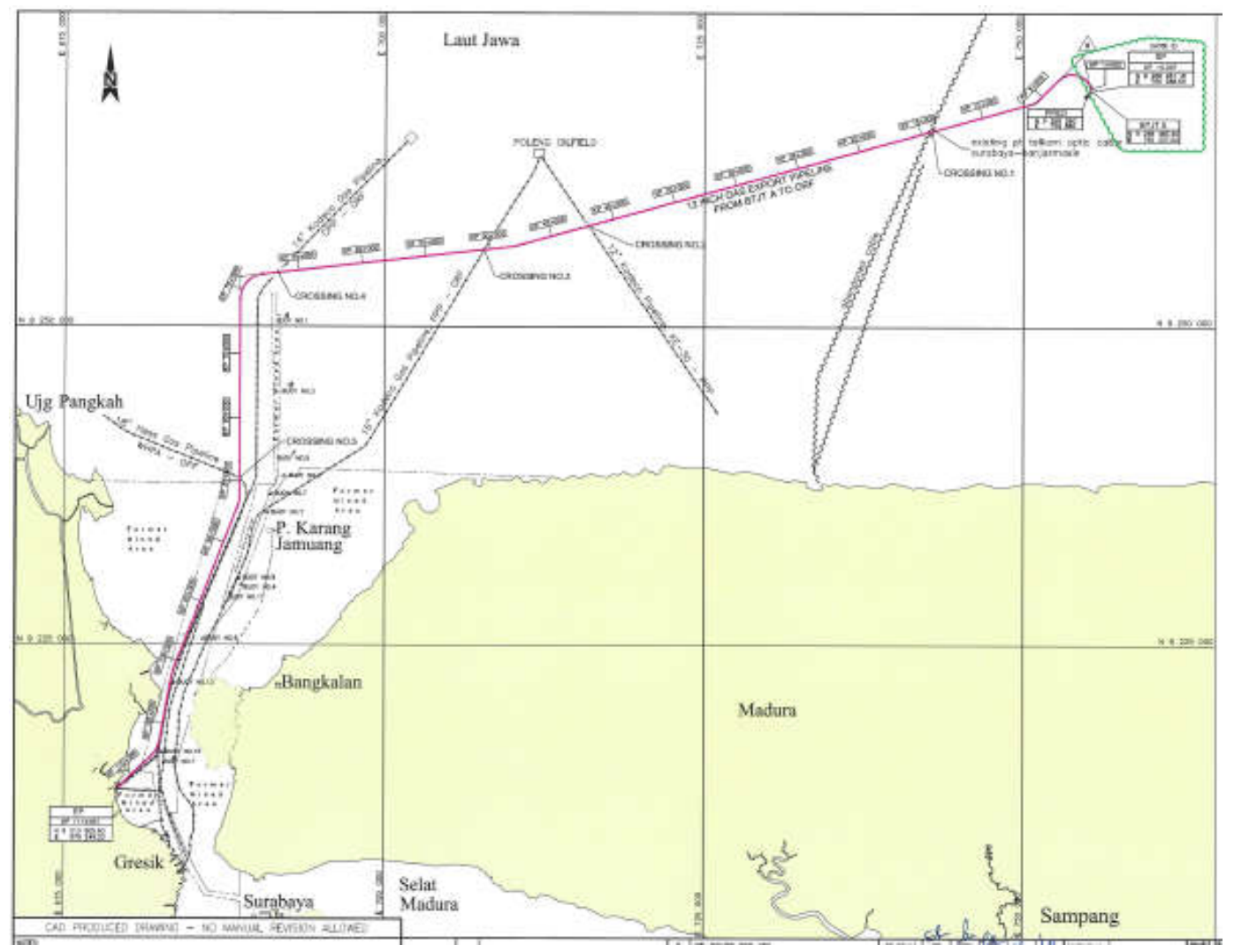

Figure 21. Pipeline Route and Crossing Location.

In their quest to deliver an exceptional project delivery, Bukit Tua project members have remained steadfast in the face of great challenges that put their strongest perseverance to test. With cohesive teamwork and incessant efforts to fulfil promises made, insurmountable challenges had become almost futile for the Project. Nonetheless, the following are key challenges that the project encountered and mitigations undertaken by Bukit Tua PMT to achieve the end target for HDD offshore crossing. Detailed key challenge and mitigation is shown in Table 1.

Table 1. Key challenges and mitigation.

\begin{tabular}{lll}
\hline No & Key Challenges & Mitigation \\
\hline 1. & HDD offshore is first time \\
installed in PCSB (or probably & Comprehensively sort out capable and experienced \\
vithin this region) & $\begin{array}{l}\text { Review in detail procedure and contractor proposal for } \\
\text { HDD execution } \\
\text { Involved resource from Head Quarter in TP level }\end{array}$ \\
& $\begin{array}{l}\text { To control pipeline profile and } \\
\text { to minimize movement on } \\
\text { both end point } \\
\text { Soft Soil in Crossing Area may } \\
\text { cause the borehole collapse }\end{array}$ & $\begin{array}{l}\text { Utilizing } 8 \text { Anchored work barge } \\
\text { Mud mixing and testing are comprehensively studied, }\end{array}$ \\
\end{tabular}


As a result, the Bukit Tua Project successfully completed HDD offshore for pipeline crossing with a vertical separation of $9.7 \mathrm{~m}$ (satisfying the minimum of $8 \mathrm{~m}$ ) from existing pipelines. Moreover, both accuracies of the entry point and exit point for the HDD are within $2 \mathrm{~m}$ radius from the targeted points. This success bears proof that excellent engineering study and superb work execution in offshore may lead to tremendous achievement to all parties.

The project at the bigger scope in Bukit Tua project has also marked a few significant achievements by itself. New benchmark has been set by Bukit Tua Project despite major challenges especially high cost, personnel competency, coordination and also concurrent activity with drilling. The project, with full support rendered by PETRONAS, responded positively to meet the schedule of in-field pipelines readiness by end-March 2015.

During offshore campaign, the project managed to complete the campaign successfully without major incident despite the fact that there were other activities (HUC Barge, Drilling Rig) at Bukit Tua Field vicinity executing simultaneous job. Most importantly though, Bukit Tua Project execution has been a continuous pursue of HSE Excellence and Zero Tolerance from the beginning thus recent offshore project achievement of 5.16 Million Manhours without LTI does not come as surprise for the project. Photograph image of the project result is shown in Figures $\mathbf{2 2}$ and 23.

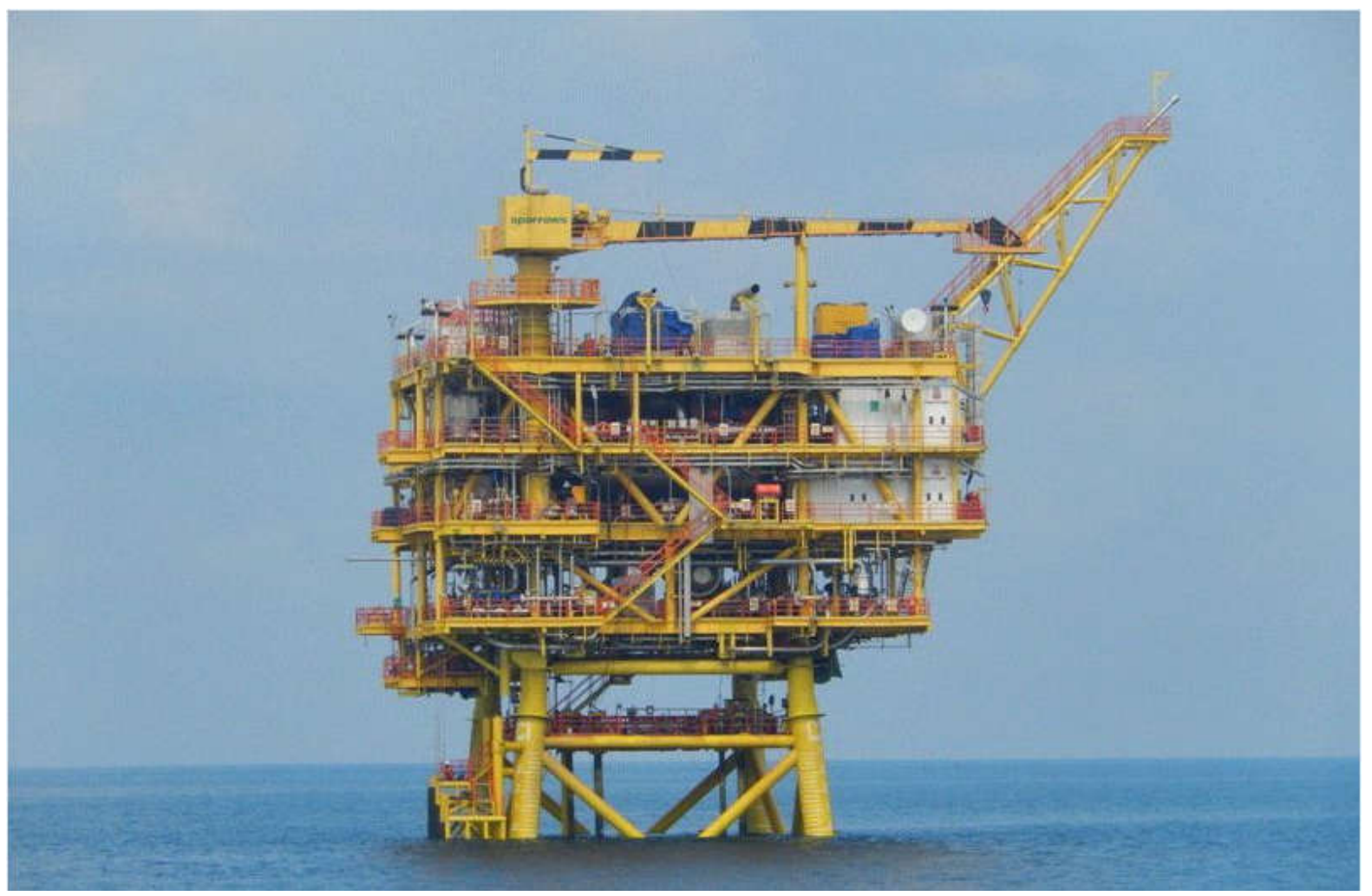

Figure 22. The photograph image of plant taken from $1 \mathrm{~km}$. 


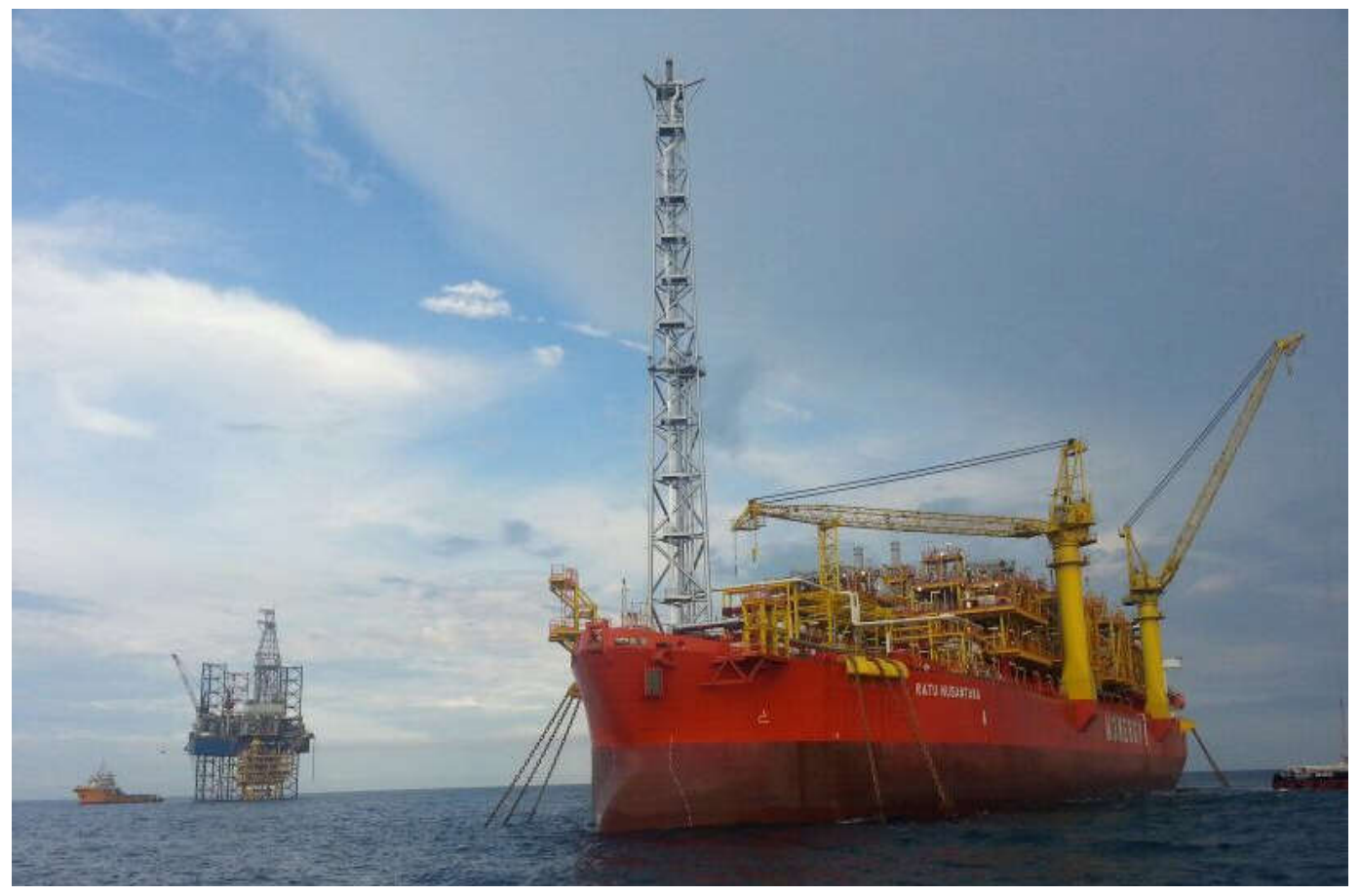

Figure 23. The photograph image of plant taken from $3 \mathrm{~km}$.

Based on the above results, we get several key success factors. The key success factors include

1. Support from management to undertake important decisions

2. Doings things differently by challenging CONTRACTOR's proposal and seek alternatives

3. Can do and never say die-attitude to continuously push boundaries and creative problem solving amidst great challenges

Cultivation of PETRONAS culture \& way of doing things to local staffs- reinforcement team sets good example for emulation and instilling of PETRONAS mindset. ( i.e HSE, urgency, governance).

\section{CONCLUSION}

In conclusion, to get success in constructing Bukit Tua project, several key lesson learned are
1. Underestimate of risk in a newly ventured country with integrated development- more detailed analysis for project execution to include cost and schedule risk analysis to minimize underestimate of project and country risk

2. Selection of contractors in skilled resource-constraint country-> financially problematic and non-performing contractors will spell disasters to execution, despite authority requirement

3. Right focus on critical path activities that Timely completion of in-field pipeline pre-commissioning as critical path will warrant ahead of schedule 1st Oil

4. Stakeholders management is essential especially in bureaucratic host country

5. Strength of project manager in managing non-performing local contractors requisition of reinforcement team from $\mathrm{HQ}$ to support local staff 
Yusuf Sofyan. Project for Offshore Horizontal Directional Drilling (HDD) for Pipeline... | 202

Bukit Tua Project journey has been enriching new experience to Petronas as PSC Operator of which the knowledge and experience gained are indeed invaluable. Those priceless PLLs on exemplary feats would be worth to be replicated in future projects.

After weathering perfect storm of challenges, the company could now reap the fruit of the hardwork and enjoy the sweetness of success in a more meaningful way. The achievements are not only testament of Petronas' ability to deliver another world-class project, but also substantiate its continuous capability to realize one more exemplary, reimagined project.

\section{ACKNOWLEDGEMENTS}

Authors thank to Petronas for its support for this study

\section{AUTHORS' NOTE}

The author(s) declare(s) that there is no conflict of interest regarding the publication of this article. Authors confirmed that the data and the paper are free of plagiarism.

\section{REFERENCES}

Benmedjahed, M., \& Boudaoud, L. (2015). Temporal Assessment of Wind Energy Resource in Algerian Desert Sites: Calculation and Modelling of Wind Noise. Journal of Fundamentals of Renewable Energy and Applications, 5 (3), 1-4

Farobie, O., \& Hasanah, N. (2016). Artificial Neural Network Approach to Predict Biodiesel Production in Supercritical tert-Butyl Methyl Ether. Indonesian Journal of Science and Technology, 1(1), 1-22.

https://www.pik-potsdam.de/research/publications/pikreports/.files/pr80.pdf\#page $=458$ (Accessed on 5 May 2016)

Kathare, R. V., \& Undre, P. G. (2016). Role and Applications of Nanotechnology for Energy Production, International Journal of Engineering Technology Science and Research, $3(3), 5-7$

Kumar, S., Ghaly, A. E., \& Brooks, M. S. (2015). Production of Biodesiel from Animal Tallow via Enzymatic Transesterification using the Enzyme Catalyst Ns88001 with Methanol in a Solvent-Free System. Journal of Fundamentals of Renewable Energy and Applications, 5(2), 1-8

Ryder, A. A., \& Rapson, S. C. (2008). Pipeline technology. In Environmental technology in the oil industry (pp. 229-280). Springer Netherlands.

Ryder, A. A., Rapson, S. C., \& Domeney, R. A. (2016). Pipeline Technology and the Environment. In Environmental Technology in the Oil Industry (pp. 321-373). Springer International Publishing.

Sharma, Y. C., \& Singh, B. (2009). Development of biodiesel: current scenario. Renewable and Sustainable Energy Reviews, 13(6), 1646-1651.

Sucahya, T.N., Permatasari, N. and Nandiyanto, A.B.D., 2016. Review: Fotokatalis untuk pengolahan limbah cair. Jurnal integrasi proses, 6(2), 1-15. 